\title{
イットリア安定化ジルコニアの高温安定性 High Temperature Stability of Yttria Stabilized Zirconia
}

\author{
小川光惠* \\ Mitsue Ogawa
}

\begin{abstract}
イットリア安定化ジルコニアは熱物性に関する標準物質候補材料として研究が進められている。 本研究では、ファインセラミックス共通試料であるリファセラム ZR1（ジルコニア）を用い、標 準物質材料として使用する際に重要となる高温安定性の評価を行った。高温安定性は、200〜 $1500^{\circ} \mathrm{C}$ の温度で熱処理を行ったときの、熱処理前後の熱拡散率の変化より評価した。 $900^{\circ} \mathrm{C}$ 以下の 熱処理では熱拡散率に変化がほとんど見られなかったが、 $1000^{\circ} \mathrm{C}$ 以上で熱処理すると、結晶相の 変化や相分離および粒界に発生した亀裂などによって熱拡散率に変化が生じることが明らかにな った。これらの結果より、リファセラム ZR1 は 900ㄷ以下であれば安定であり、標準物質として 適用できると判断された。

Yttria stabilized zirconia (YSZ) has been studied as a candidate reference material for thermophysical properties. In this study, the high-temperature stability of thermal diffusivity has been evaluated using Referceram ZR1 which was originally developed as a reference material for mechanical testing of fine ceramics. Thermal diffusivity of specimens before and after heat-treatment at various temperatures between 200 and $1500^{\circ} \mathrm{C}$ in air were measured by laser flash method. The heat-treatment at $900{ }^{\circ} \mathrm{C}$ effected little change in thermal diffusivity. However, after heat-treatment at $1000{ }^{\circ} \mathrm{C}$ or above, thermal diffusivity values were effected by phase separation, phase transportation, crack occurred in grain boundary, and so on. Therefore ZR1 should be used as a thermophysical reference material at temperatures below $900^{\circ} \mathrm{C}$.
\end{abstract}

[Keywords : thermal diffusivity, zirconia, 3YSZ, high temperature stability, heat-treatment]

\section{1. 緒言}

ジルコニアは低熱伝導率、導電特性、高強度など多 くの機能を有したセラミックスで、遮熱コーティング や燃料電池、生体材料など多方面での利用が期待され ている。材料の実用化においては、物性の把握が必要 であるが、特に高温部材として用いる場合には熱物性 データが重要となるため、熱物性の精度よい評価が求 められる。熱拡散率の標準物質としてはアルミナを用 いた TD-AL[1-2]が（財）ファインセラミックスセンタ 一（JFCC）より供給されている。しかし、ジルコニア はアルミナに比べて熱拡散率が $1 / 10$ と小さいことや、 開発材の熱拡散率を評価する上で、比較の基準となる 材料も必要であることなどから、同じ材質のジルコニ アでできた標準物質の開発が望まれている。熱伝導に

* (財)ファインセラミックスセンター 材料技術研究所 研 究第二部 干456-8587 愛知県名古屋市熱田区六野 2-4-1. Japan Fine Ceramics Center, 2-4-1 Mutsuno, Atsuta-ku, Nagoya, Aichi, 456-8587.

FAX : 052-871-3599 E-mail : mitsue@jfcc.or.jp
関する標準物質の供給は、これまで国際的には米国の 国立標準技術研究所 (National Institute of Standards and Technology，NIST)に主に依存してきているが、ジルコ ニアを用いた標準物質は供給されていない。リファセ ラムはファインセラミックスの共通試料として JFCC で 開発されたものである $[3]$ 。リファセラムには、AL1（ア ルミナ）、SN1（窒化ケイ素）、ZR1（ジルコニア）の 3 種類がある。このうち、AL1 については、すでに熱拡散 率標準物質 TD-AL として JFCC より供給されている。ま た、ZR1 についても、熱拡散率標準物質の候補材料とし て均質性の検討が行われており、有望な材料であるこ とが明らかにされている[4]。さらに、遮熱コーティン グの熱物性計測用の標準物質として、ジルコニアをコ ーティング材とした材料の開発も進められている [5]。 標準物質においては、使用温度範囲内で試料寸法や 物性が変化しないという安定性が不可欠である。熱拡 散率標準物質 TD-AL の原材料であるリファセラム AL1 についても安定性の評価が行われている $[6]$ 。これによ ると、リファセラム AL1 は焼成温度である $1590^{\circ} \mathrm{C}$ り 
低い温度でも、長時間保持により粒成長し、熱拡散率

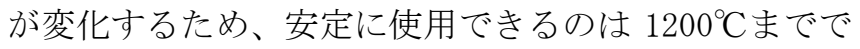
あると報告されている。このようにセラミックスでは 高温で保持することにより物性に変化をきたすことが あるため、安定性について十分に評価しておく必要が ある。そこで、ジルコニアを用いた熱物性標準物質を 開発するため、リファセラム ZR1 について熱拡散率の 安定性を評価し、標準物質として適切に使用できる温 度範囲の検討を行った。

\section{2、試料および実験方法}

\section{1 試料}

本研究では、セラミックスの各種試験や加工等の共 通試料として開発されたリファセラムの中の ZR1 (ジル コニア）を用いた。リファセラムは JFCC が関連機関と 共同で開発したものであり、厳密な品質管理のもとに 品質の安定性を保って製造されている[1]。

純粋なジルコニアは室温から高温になるにつれて、 単斜晶、正方晶、立方晶へと結晶相が変化する。この 相転移に伴う体積変化は大きく、焼結時の冷却におい て材料にき裂が生じてしまうため実質的に使えない。 そこで、イットリア $\left(\mathrm{Y}_{2} \mathrm{O}_{3}\right)$ やマグネシア $(\mathrm{Mg} 0)$ 等の 安定化剂を微量添加することにより、高温域の結晶相 である立方晶や正方晶の安定領域が低温側にも広がり、 室温でも立方晶や正方晶が存在できるようになる。リ ファセラム ZR1 は、安定化剤に 3 mol\%のイットリアを

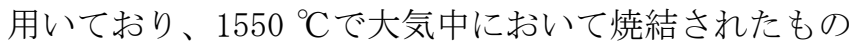
である。室温での結晶相は正方晶である。リファセラ ム ZR1 の化学組成を Table 1 に、室温における主な特 性值を Table 2 に示す。なお、原料粉体特性や製造プ ロセス等はテクニカルレポート[7]として公開されて いる。

試験加工用共通試料として供給される時の標準形状 は $80 \times 50 \times 5 \mathrm{~mm}$ の板状(標準板) であり、安定性評価用 の試料はこの標準板より切り出した。

\section{2 測定方法}

熱拡散率測定用に加工された試料を、所定の温度 (大 気中）で熱処理し、熱処理による熱拡散率の変化から 安定性を評価した。熱処理前後の熱拡散率測定は室温 で行った。熱拡散率はレーザーフラッシュ法で測定し
Table 1 Chemical composition of Referceram ZR1.

\begin{tabular}{|c|c|}
\hline Composition & contents (wt $\%)$ \\
\hline $\mathrm{ZrO}_{2}+\mathrm{HfO}_{2}$ & $>94.0$ \\
\hline $\mathrm{Y}_{2} \mathrm{O}_{3}$ & $<5.65$ \\
\hline $\mathrm{Al}_{2} \mathrm{O}_{3}$ & $<0.30$ \\
\hline $\mathrm{SiO}_{2}$ & $<0.02$ \\
\hline $\mathrm{Fe}_{2} \mathrm{O}_{3}$ & $<0.01$ \\
\hline $\mathrm{Na}_{2} \mathrm{O}$ & $<0.04$ \\
\hline
\end{tabular}

Table 2 Physical properties of Referceram ZR1.

\begin{tabular}{|c|c|}
\hline Bulk Density & $6070 \mathrm{~kg} / \mathrm{m}^{3}$ \\
\hline Fracture Toughness & $5.0 \mathrm{MPa} \cdot \mathrm{m}^{1 / 2}$ \\
\hline Flexural Strength & $1100 \mathrm{MPa}$ \\
\hline Hardness & $1300(\mathrm{HV} 10)$ \\
\hline Thermal Conductivity & $3.1 \mathrm{~W} /(\mathrm{m} \cdot \mathrm{K})$ \\
\hline $\begin{array}{c}\text { Thermal Expansion } \\
\text { Coefficient }\end{array}$ & $11.1 \times 10^{-6} /{ }^{\circ} \mathrm{C}$ \\
\hline
\end{tabular}

た。試料形状は $\phi 10 \times 2 \mathrm{~mm}$ である。装置は京都電子工 業製の LFA-501 および LFA-502 である。試料表面には AuPd を両面にコーティングした後、dgf（ドライグラフ アイトフィルム) を塗布し、測定を行った。熱拡散率 はカーブフィッティング法 [8-9]を用いて求めた。

また、曲げ共振法による内部摩擦測定を行った。内 部摩擦は材料の相転移や粒子振動などを表すもので、 曲げ共振法による弾性率測定における周波数ピーク形 状より求めることができる。内部摩擦測定には $80 \times$ $10 \times 2 \mathrm{~mm}$ の形状の試料を用いた。さらに、電子走查顕 微鏡（SEM）による試料の微細構造観察、X 線回折によ る結晶構造解析を行った。微構造観察、X 線回折は熱拡 散率を測定した $\phi 10 \times 2 \mathrm{~mm}$ の試料を用いた。

\section{3．測定結果および考察}

Fig. 1 に室温から $1400^{\circ} \mathrm{C}$ における内部摩擦測定結果 を示す。なお、測定した試料は熱処理を行っていない ものである。内部摩擦は $200^{\circ} \mathrm{C}$ 付近でピークをもち、さ 
らに $1200^{\circ} \mathrm{C}$ 超えたあたりから急激な増大を示した。 イットリア安定化ジルコニアは $200^{\circ} \mathrm{C}$ 付近で立方晶か ら単斜晶へ相変態を生じ、粒径や強度が変化すること が報告されている $[10] 。 200^{\circ} \mathrm{C}$ 付近のピークに関しては、 この相変化に関係するものと考えられる。一方、 $1300^{\circ} \mathrm{C}$ を超えた温度域での内部摩擦の増大については、粒成 長が関与しているものと推測される。

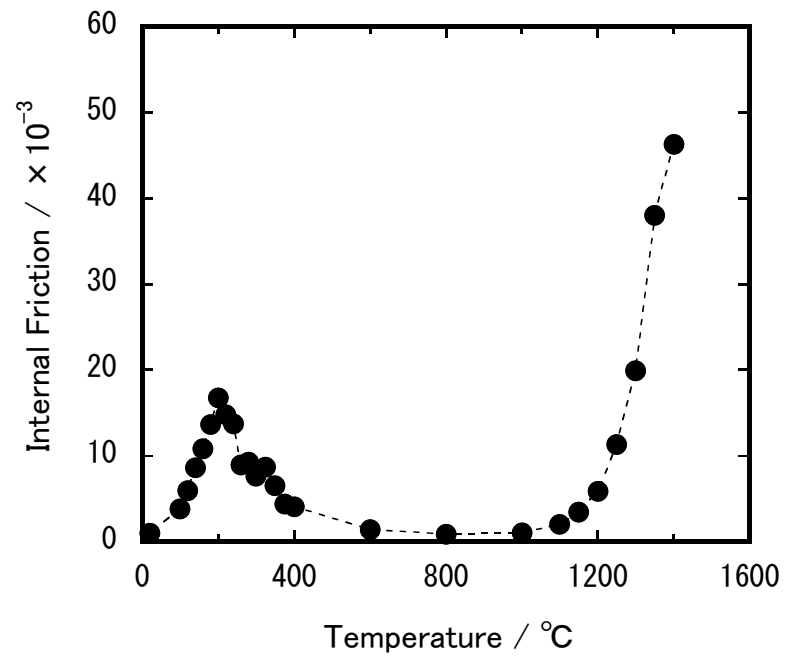

Fig.1 Internal friction of ZR1 before heat-treatment.

内部摩擦の結果より、比較的低温域においても相変 化を起こす可能性があるため、熱処理温度を $100^{\circ} \mathrm{Cから}$ $1500^{\circ} \mathrm{C}$ とし、100 時間熱処理を行った。このときの、熱 処理温度に対する熱拡散率の変化を Fig. 2 に示す。な お、熱拡散率の変化は熱処理後の熱拡散率 $\alpha$ と熱処理 前の熱拡散率 $\alpha_{0}$ の差 $\Delta \alpha$ より、 $\Delta \alpha / \alpha_{0}(\%)$ で表した。 熱処理前の熱拡散率 $\alpha_{0}$ は $1.1 \times 10^{-7} \mathrm{~m}^{2} \mathrm{~s}^{-1}$ であった。

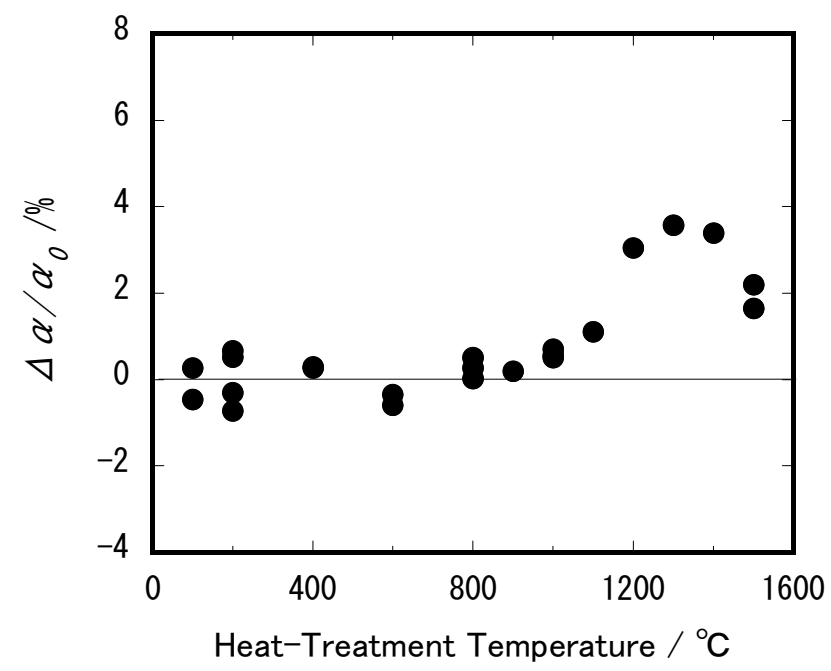

Fig.2 The difference in thermal diffusivity before and after heat-treatment for $100 \mathrm{~h}$.
熱処理温度 $1100^{\circ} \mathrm{C}$ までは熱拡散率に大きな変化は見 られなかったが、 $1200^{\circ} \mathrm{C}$ 以上で熱処理したものでは熱 拡散率の増加が見られた。その変化は $1300^{\circ} \mathrm{C}$ までが増 加で、 $1400^{\circ} \mathrm{C}$ 以上では低下であった。

Fig. 3 にX 線回折結果を示す。 $1300^{\circ} \mathrm{C}$ 以下で熱処理を 行った試料の回折ピークは、熱処理を行う前と一致し ていた。これらのピーク形状より、結晶相は正方晶で

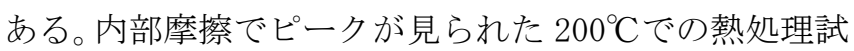
料の回折ピークも、処理を行わないものと一致してお り、リファセラム ZR 1 は $200^{\circ} \mathrm{C}$ における 100 時間程度の 熱処理では相変化を起こさないものと思われる。 $1400^{\circ} \mathrm{C}$ 以上の温度で熱処理した試料の回折ピークには、 熱処理前の試料には見られなかったピークが出現して おり、その強度は熱処理温度が高いほど大きかった。 これらのピークは単斜晶ジルコニアのピークと一致し ていた。高温で熱処理を行ったことにより、結晶相の 変化を生じたものと考えられる。

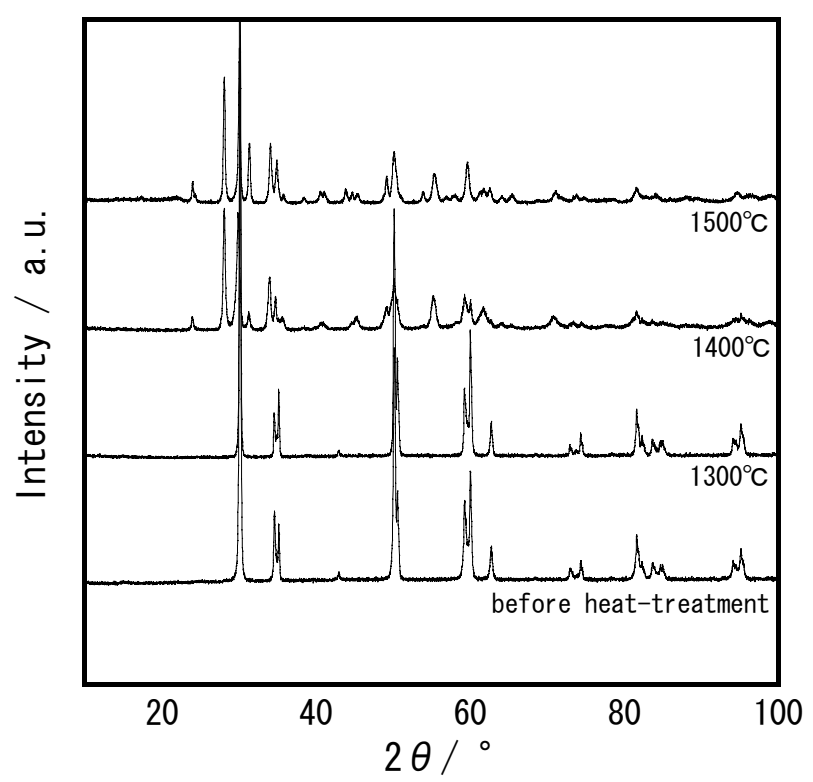

Fig.3 XRD patterns of ZR1 before and after heat-treatment for $100 \mathrm{hr}$.

試料表面の微細構造をSEM で観察した写真を Fig. 4 に示す。熱処理前の微構造に対し、 $1300^{\circ} \mathrm{C}$ で熱処理し た試料の微構造はほとんど変化が見られていない。 $1400^{\circ} \mathrm{C} 、 1500^{\circ} \mathrm{C}$ で熱処理した試料では、粒子が大きく なっており、さらに $1500^{\circ} \mathrm{C} て ゙$ 熱処理した試料では粒界 にき裂もみられた。AL1（アルミナ）の場合、熱処理に よる熱拡散率の変化は、焼結が進み緻密化したことに よるものであった。しかし、ZR1においては、熱拡散率 


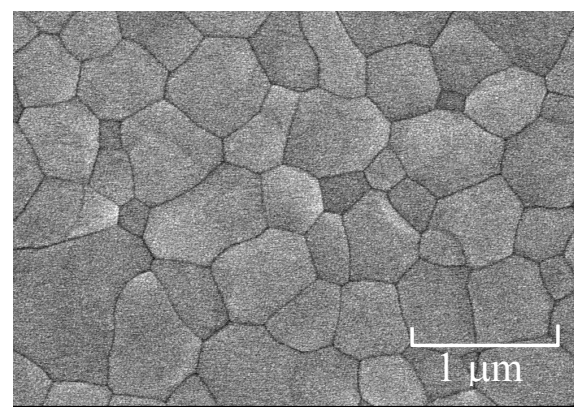

(a) before heat-treatment

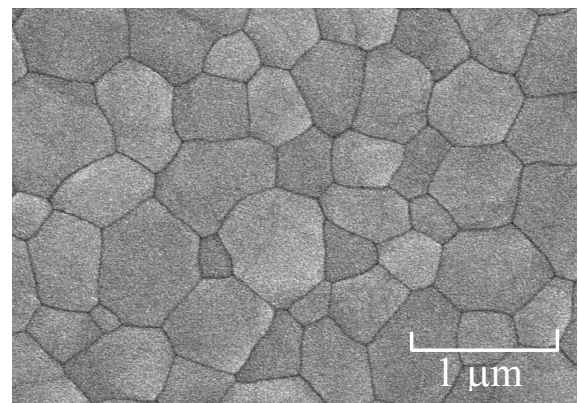

(c) heat-treatment at $1300^{\circ} \mathrm{C}$

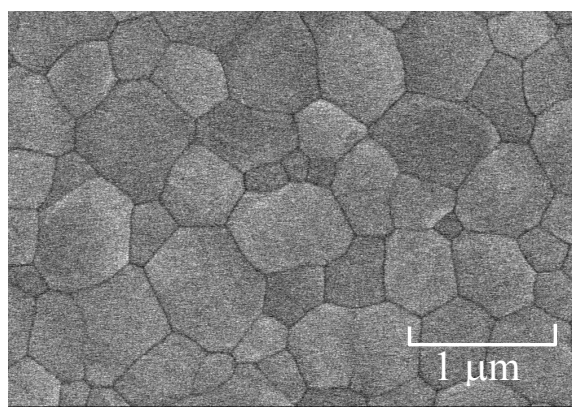

(b) heat-treatment at $800^{\circ} \mathrm{C}$

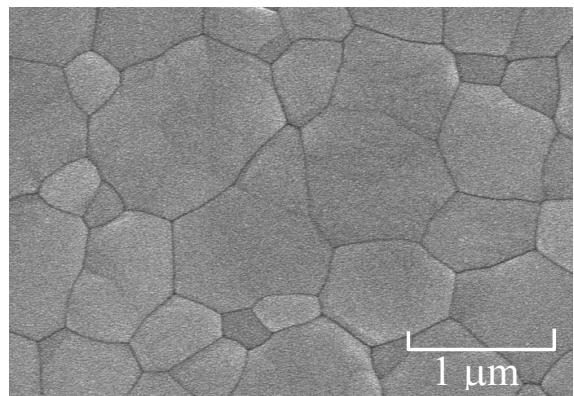

(d) heat-treatment at $1400^{\circ} \mathrm{C}$

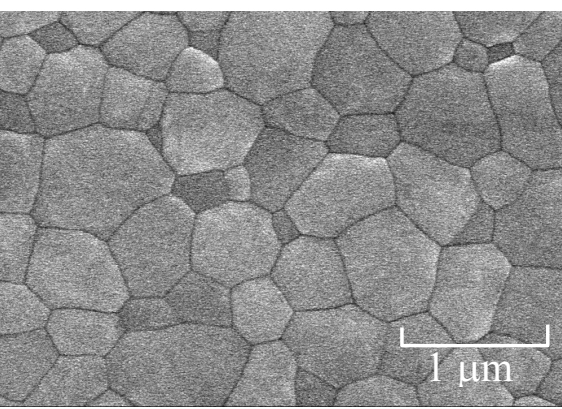

(c) heat-treatment at $1000^{\circ} \mathrm{C}$

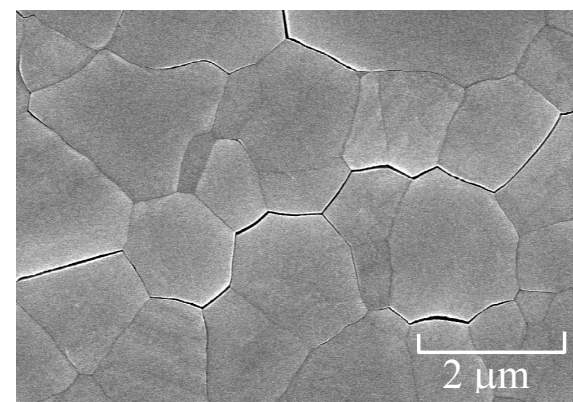

(e) heat-treatment at $1500^{\circ} \mathrm{C}$

Fig.4 Scanning electron micrographs of typical ZR1 microstructure before and after heat-treatment for 100h : (a)before heat-treatment, after heat-treatment at (b) $800^{\circ} \mathrm{C},(\mathrm{c}) 1000^{\circ} \mathrm{C},(\mathrm{d}) 1300^{\circ} \mathrm{C},(\mathrm{e}) 1400^{\circ} \mathrm{C}$, and (f) $1500^{\circ} \mathrm{C}$.

に変化が見られた $1200^{\circ} \mathrm{C} 1300^{\circ} \mathrm{C}$ で熱処理において 微構造に変化が見られていないことから、熱拡散率の 変化には、焼結による粒成長や緻密化だけでなく、別 の現象も関与していることが予想される。また、XRD

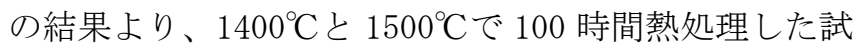
料では単斜晶相を生じていることを確認したが、正方 晶から単斜晶への相変化では体積膨張を伴うことが知 られており、これにより結晶粒径が増大し、亀裂が発 生した。 $1500^{\circ} \mathrm{C}$ 熱処理で熱拡散率が低下したのは、 これにより生じたき裂が熱抵抗となったためと考えら れる。

以上の結果より、リファセラム ZR 1 は $1400^{\circ} \mathrm{C}$ 以上の 温度で長時間保持すると、相変化により結晶粒が体積 膨張し、さらに熱拡散率が変化することが明らかにな った。また、結晶相や微構造に変化は現れないものの、 $1200^{\circ} \mathrm{C}$ 以上で熱処理を行うと熱拡散率が変化すること がわかった。

Sakuma らは $\mathrm{ZrO}_{2}$ リッチの $\mathrm{ZrO}_{2}-\mathrm{Y}_{2} \mathrm{O}_{3} \quad\left(\mathrm{Y}_{2} \mathrm{O}_{3}\right.$ が 2.0〜 6. $3 \mathrm{mo} 1 \%$ ）の相変化について研究しており $[11]$ 、 2. $9 \mathrm{~mol} \% \mathrm{Y}_{2} \mathrm{O}_{3}-\mathrm{ZrO}_{2}$ において、1200〜 $1800^{\circ} \mathrm{C}$ での熱処理に よって、 $\mathrm{Y}_{2} \mathrm{O}_{3}$ の組成の連続的な変化が現れるとしている。 これにより、材料内で $\mathrm{Y}_{2} \mathrm{O}_{3}$ リッチな部分と、 $\mathrm{ZrO}_{2}$ リッ
チ部分への相分離が生じる。 $\mathrm{Y}_{2} \mathrm{O}_{3}$ の熱拡散率は $\mathrm{ZrO}_{2}$ に 比べて 6 倍ほよ゙大きい $[12]$ 。このため、 $1200^{\circ} \mathrm{C}$ 以上の 温度で熱処理した試料では、相分離によって $\mathrm{Y}_{2} \mathrm{O}_{3}$ リッ チ相が出現し、これにより熱拡散率が上昇したと考え られる。

Sakuma らの研究では 2. 9mol\% $\mathrm{ZrO}_{2}-\mathrm{Y}_{2} \mathrm{O}_{3}$ における $1200^{\circ} \mathrm{C}$ 以上の熱処理で相分離の生じることが報告され ているが、 $1200^{\circ} \mathrm{C}$ 以下の温度による相分離の有無につ いては報告されていない。100 時間の熱処理では $1100^{\circ} \mathrm{C}$ 以下において変化が見られなかったが、より長時間保 持した場合、相分離を生じる可能性がある。そこで、 安定に使用できる温度を見極めるため、 $900^{\circ} \mathrm{C} 、 1000^{\circ} \mathrm{C} 、$ $1100^{\circ} \mathrm{C} 、 1200^{\circ} \mathrm{C} 、 1300^{\circ} \mathrm{C}$ において 500 時間まで熱処理 を行い、熱拡散率を測定した。さらに、内部摩擦がピ

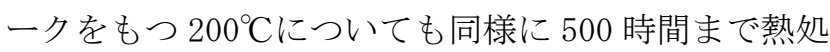
理を行った。Fig. 5 に熱処理時間に対する熱拡散率の変 化を示す。 $200^{\circ} \mathrm{Cおよび} 900^{\circ} \mathrm{C}$ では熱拡散率の変化はほ とんどみられないが、 $1000^{\circ} \mathrm{C}$ 以上では熱拡散率が増大

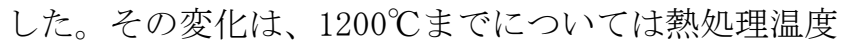

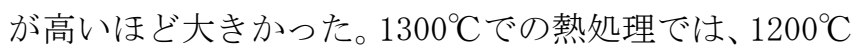
の場合と同程度の変化であった。

$200^{\circ} \mathrm{C}$ おび $1000 \sim 1300^{\circ} \mathrm{C}$ で 500 時間の熱処理を行 
たときの XRD 回折結果を Fig. 6 に示す。 $1100^{\circ} \mathrm{C}$ で熱処 理を行った試料については、熱処理前と回折パターン は変わっていない。しかし、 $1300^{\circ} \mathrm{C} て ゙$ 熱処理を行った 試料では他とは大きく異なる回折パターンが観察され た。同様の回折パターンは $1300^{\circ} \mathrm{C} て ゙ 250$ 時間熱処理し た試料にもみられた。これらのピークは $1400^{\circ} \mathrm{C} と$ $1500^{\circ} \mathrm{C}$ で 100 時間熱処理を行ったときに現れたピーク と同じで、単斜晶への相変化により生じたものである。 一方、 $200^{\circ} \mathrm{C}$ と $1200^{\circ} \mathrm{C}$ で熱処理した試料の XRD パターン

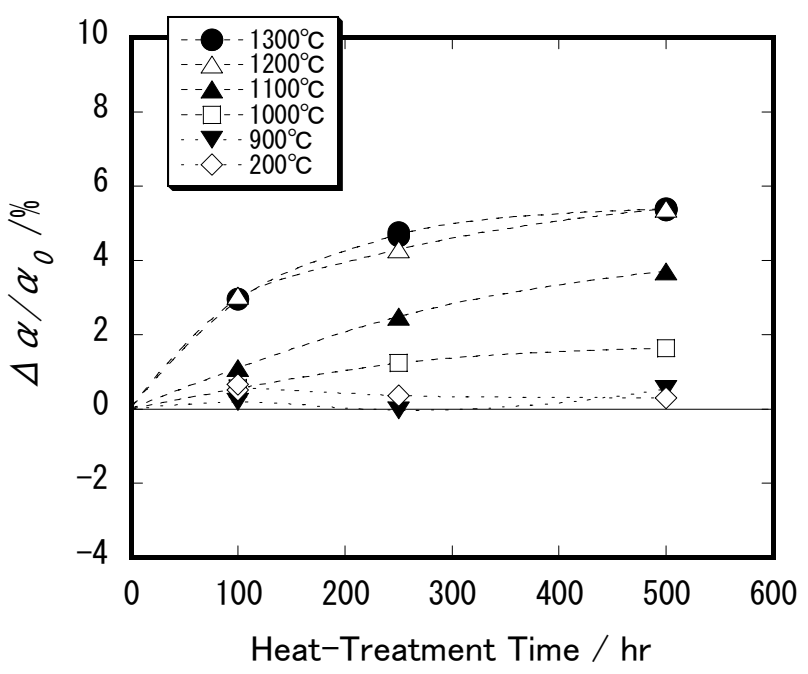

Fig.5 The difference in thermal diffusivity before and after heat-treatment.

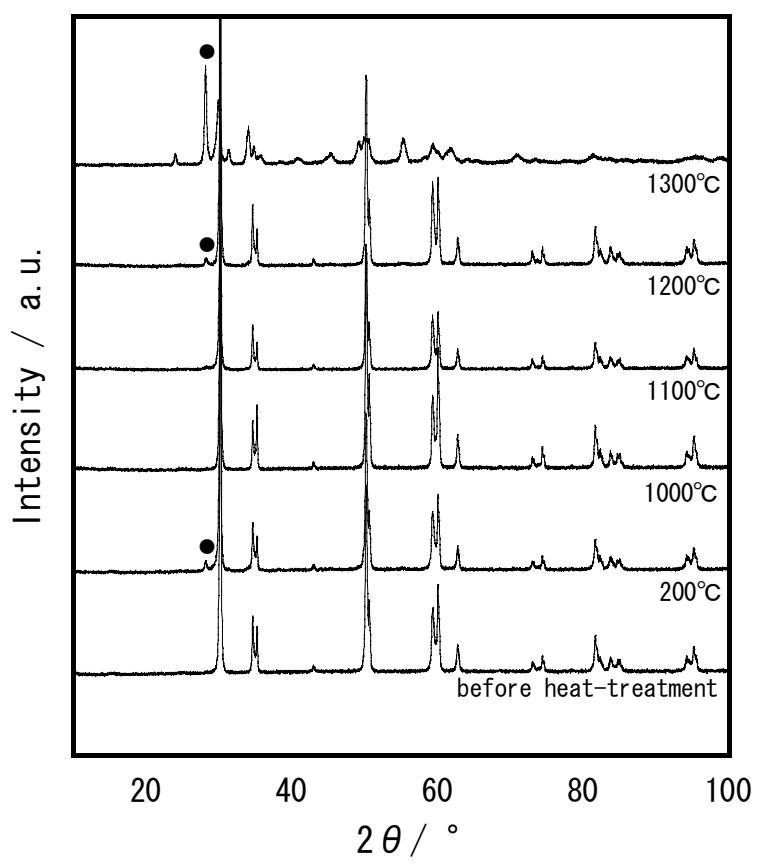

Fig.6 XRD patterns of ZR1 before and after heat-treatment for $500 \mathrm{hr}$.
には単斜晶のものと思われるピークが確認された

（Fig. 6 中の○のピーク）。イットリア安定化ジルコニ アを $200^{\circ} \mathrm{C}$ 付近で熱処理した場合、表面において相転位 が進行するが、内部では変化がきわめて遅い[13]。さ らに、結晶粒径が $0.4 \mu \mathrm{m}$ 以下であれば $200^{\circ} \mathrm{C}$ の熱処理 において熱安定性が向上する [14]。Fig. 4(a)の微構造 観察写真より求めたリファセラム ZR1の平均粒径は

$0.4 \mu \mathrm{m}$ であった。これらより、200 Cで熱処理した ZR1 では、表面付近で単斜晶への相変化が生じたが、内部 では相変化がほとんど生じておらず、その結果、熱拡 散率に変化が現れなかった。また、熱処理温度 $1200^{\circ} \mathrm{C}$ については、相変化によりピークが出現したといえる。

500 時間熱処理を行った試料の微細構造を SEM によ り観察した。観察写真を Fig. 7 に示す。 $900^{\circ} \mathrm{C} \sim 1200^{\circ} \mathrm{C}$ で熱処理した試料の微細構造は温度によらず同様で、 熱処理前のもの (Fig. 4(a)) と変化はみられなかった。 相変化、相分離が生じたと予想される $1300^{\circ} \mathrm{C}$ で 500 時 間熱処理した試料の微細構造（Fig. 7(b)）は、熱処理

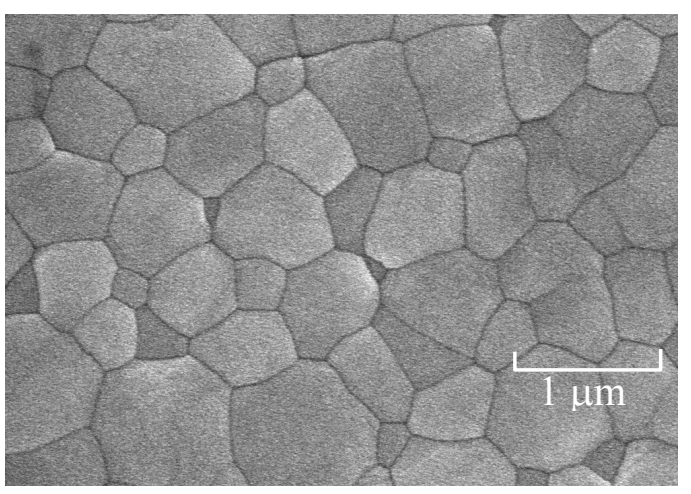

(a) heat-treatment at $1200^{\circ} \mathrm{C}$

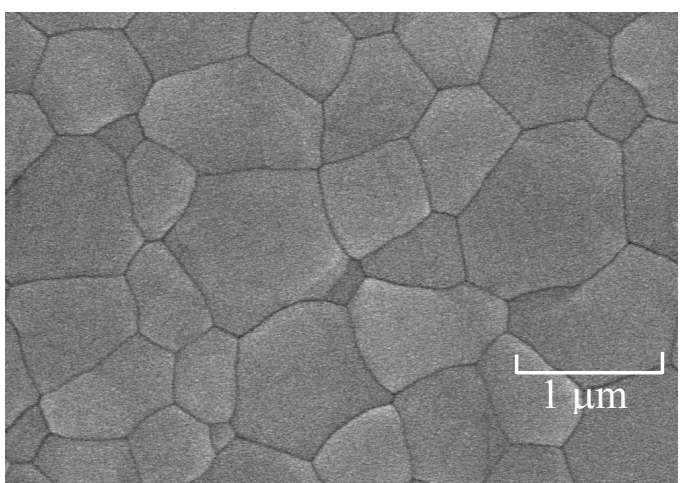

(b) heat-treatment at $1300^{\circ} \mathrm{C}$

Fig.7 Scanning electron micrographs of typical ZR1 microstructure after heat-treatment for $500 \mathrm{~h}$ : (a) $1200^{\circ} \mathrm{C}$ and (b) $1300^{\circ} \mathrm{C}$. 
前のものと比べて粒子が大きくなっていた。これは、 結晶相が正方晶から単斜晶へ変化したことによって生 じる体積膨張、および粒成長によるものと考えられる。 以上の結果より、3mo1\%イットリア安定化ジルコニア を安定に使用できる温度は $900^{\circ} \mathrm{C}$ 以下であり、この温度 であれば熱拡散率に変化がほとんどなく、標準物質と して適用できることが明らかになった。安定性が確認 された室温から $900^{\circ} \mathrm{C}$ における ZR1 の熱拡散率を Fig. 8 に示す。これは、同一試料を 2 回測定した結果である。

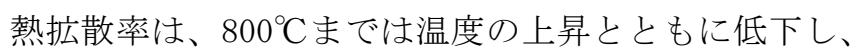
$900^{\circ} \mathrm{C}$ でわずかに高くなった。

\section{4. 結 論}

3mo1\%イットリア安定化ジルコニアリファセラム ZR1 の熱拡散率に及ぼす高温熱処理の影響を評価した。 $900^{\circ} \mathrm{C}$ 以下の熱処理では 500 時間保持しても熱物性や試 料形状に変化が見られなかったが、 $1000^{\circ} \mathrm{C}$ 以上で熱処 理した場合は熱拡散率が変化することが明らかになっ た。これは、熱処理によって結晶相の変化や相分離が 生じることによるもので、1000〜 $1200^{\circ} \mathrm{C}$ では相分離に よる熱拡散率の上昇、 $1300^{\circ} \mathrm{C}$ 以上では相分離と相変化 による変化と推測された。これらの結果より、3mol\%イ ットリア安定化ジルコニアは $900^{\circ} \mathrm{C}$ 以下であれば安定 であり、標準物質として適用できると判断された。

12

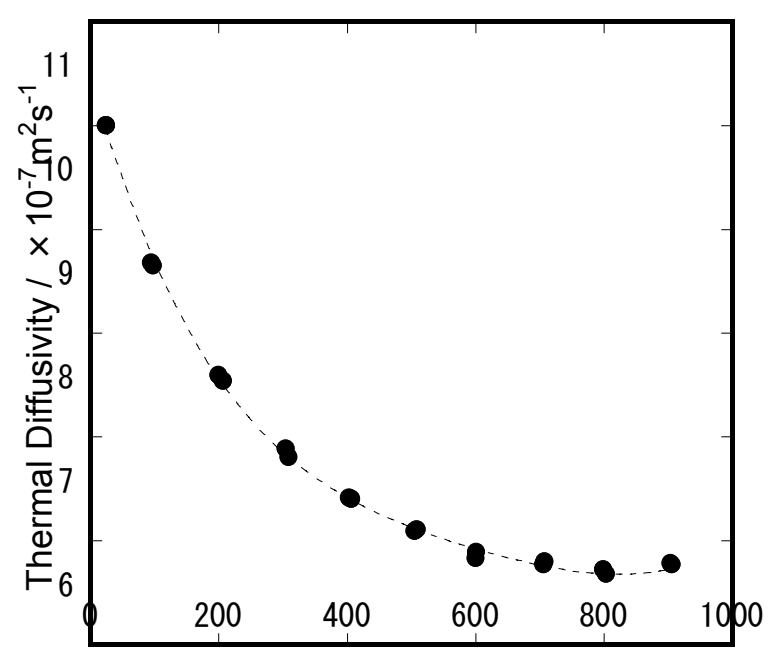

Temperature $/{ }^{\circ} \mathrm{C}$

Fig.8 Thermal diffusivity of ZR1.

\section{[謝辞］}

本研究は、科学技術振興調整費 知的基盤整備推進 制度「機能材料の熱物性計測技術と標準物質」、およ び新エネルギー・産業技術総合開発機構（NEDO）の委 託事業「ナノテクノロジープログラム ナノ計測基 盤技術 熱物性の計測基盤の研究」として行われたも のである。

\section{NOMENCLATURE}

$\alpha \quad:$ thermal diffusivity, $\mathrm{m}^{2} \mathrm{~s}^{-1}$

$\alpha_{0}:$ thermal diffusivity before heat-treatment, $\mathrm{m}^{2} \mathrm{~s}^{-1}$

$\theta \quad$ : incident angle of X-ray

\section{参考文献}

[1] 小川光恵、馬場哲也、向井一夫、内藤牧男 ; 熱物 性、12 (1998), 114-119.

[2] M.Ogawa, K.Mukai, T.Fukui, T.Baba; Measurement Science and Technology, 12 (2001), 2058-2063.

[3] 平成4年度通商産業省無機新材料産業対策調査、 “ファインセラミックス評価手法調査研究報告 書”、ファインセラミックスセンター、(1993), 93.

[4] 小川光恵、向井一夫、福井武久 ; 第23回日本熱物性 シンポジウム講演論文集、(2002),226-228.

[5] 小川光恵、向井一夫、水野峰男、馬場哲也 ; 第26 回日本熱物性シンポジウム講演論文集、(2005), 168-170.

[6] 小川光惠、小川秋水、向井一夫; 熱物性、 17 (2003),162-167.

[7]（財）ファインセラミックスセンター ; テクニカ ルレポート TR-AL1、(1994).

[8] A.Cezairliyan, T.Baba, R. Taylor ; Inter. J. of Thermophysics, 15 (1994), 317-341.

[9] 馬場哲也; 第 17 回日本熱物性シンポジウム講演論文集、 (1996), 379-3.

[10] K.Kobayashi, H.Kuwajima. T. Masaki ; Solid State Ion., (1981) 489-493.

[11] T.Sakuma, Y.Yoshizawa. H.Suto ; J. Mater. Sci., 21 (1986) 1436-1440.

[12］日本熱物性学会;「熱物性ハンドブック」250 頁 (養 賢堂、1990).

[13] 佐藤次雄、大滝史郎、遠藤忠、島田昌彦 ; 「ジル コニアセラミックス 5」(宗宮重行、吉村昌弘編), 75-85 頁 (内田老鶴圃, 1985).

[14] 河村利夫、大西宏司 ; 「ジルコニアセラミックス 4」(宗宮重行、吉村昌弘編), 31-45 頁 (内田老鶴固, 1985).

[Received Nov.14, 2006, Accepted Jan.23, 2007] 